\title{
Popular Destinations in Tourism: Case Study of TripAdvisor
}

\author{
Annisa Pratiwi \\ Tourism Department, Vocational Education Program, Universitas Indonesia \\ *Email: pratiwi.annisa@ hotmail.com
}

\begin{abstract}
In the modern era, it has become very popular to share travel experiences on the Internet. This study focuses on a common trend among tourists: the travel experience toward positive and negative travel experience's review shared on TripAdvisor. The study analyzed a sample of the top five most visited attractions in Bali based on TripAdvisor.com. The information available on forums and reviews is generated by the consumer, and provides relevant data for travel planning.
\end{abstract}

Keywords: social media, TripAdvisor, tourist attractions

\section{Introduction}

The innovation of information and communications technology (ICT) has empowered tourists to explore tourism destinations more easily. The continuous development of new tourist destinations and the growth of the existing ones demand the need for responsible destinations to maintain promotion as an attraction.

A growing number of tourists worldwide are no longer dependent on travel agencies to search for information, inspiration, and motivation for their destination holiday. Since the early e-Tourism studies (Buhalis \& Law, 2008), information systems have provided tourism information and tourists' behaviors. Through websites, tourists are well-informed by useful platforms especially for tourism destinations, such as Expedia, Booking.com, TripAdvisor, Wikitravel, etc. Expedia and Booking.com are websites that facilitate reservation and price comparison, while TripAdvisor and Wikitravel are websites that provide information, reviews, and recommendations.

According to an ITB Berlin study from 2016, with a percentage of $24 \%$, the Internet is the leader in tourism sales. Every successful business, not only in tourism, must be digitally promoted as well (Paulina, Cezar, \& George, 2009). From all websites, tourists have mostly used the Internet to browse for inspiration, motivation, and information about their next potential destination (ETC 2012). Tourists have read various kinds of reviews and comments on many platforms. From this online search, they could decide where they would stay or how they would reach their destination. From this trend, tourism destinations worldwide are becoming an important focus of attention for tourists' decision-making process. Because of the revolution of Internet technology, tourists nowadays are capable of sharing travel-related information, personal experiences, and opinions via text comments, photographs, and videos on social media during or after a trip (Kang \& Schuett, 2013).

As a form of electronic word of mouth (e-WOM), shared travel experiences on social media play an important role in shaping tourists' awareness, expectations, perceptions, attitudes, and behaviors (Liu, Wu, \& Li, 2019). The purpose of this paper is to understand and discuss the reviews and comments from tourists in shared travel experience networking onTripAdvisor. The intention of this study is to identify consumer-generated content (CGC) on TripAdvisor with a case study on the island of Bali, and to discuss and verify the tourists' reviews of tourist attractions in Bali. To meet these objectives, data was collected from TripAdvisor on the top five attractions in Bali. This paper is structured starting from the first two sections where the literature is reviewed, and the research questions are formulated. The third section describes the sample and the dimension and presents the major findings. The presentation of findings is followed by a discussion of their implications for theory and practice.

\section{Literature Review}

A recent study confirmed that the growing number of tourists who use the Internet to look for information about destinations and to make reservations online has increased (Amaral, Tiago, \& Tiago, 2014). Earlier studies have focused on the impact of eWOM on travel decisions or image formation. However, specific websites in the travel context, such as TripAdvisor, formed the basis of these studies (Miguéns, Baggio, \& Costa, 2008). The 
Internet embodies access that is available any time, any place, thus providing a clear summary of the information and representing a significant, decisive element in the purchase. A well-informed tourist is an educated one as well, regarding the language and culture of the destination country; they know the products and services that meet their needs, and where and when to find the special offers and prices that the market supplies (Mihalcescu, Sion, \& Marginean, 2016).

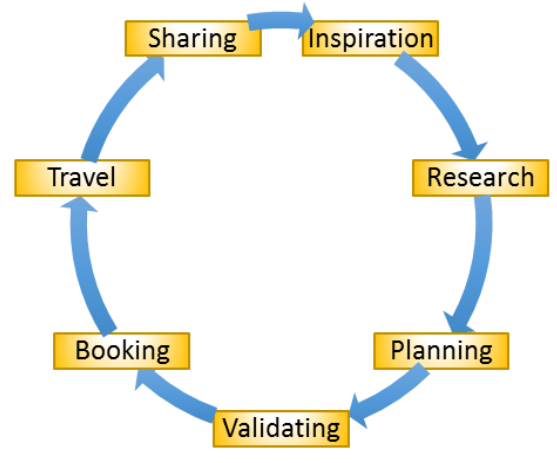

Fig. 1 Experience-Mapping Traveler, Robert Cole; Leverage on ICT at each stage of the Travel Experience

Several studies examine the concern of online reviews, or e-WOM, focusing mainly on matters such as motivations of and social influences between users of and contributors to review sites. However, from previous studies, the impact of online reviews cannot be investigated on consumer decision-making, such as to what extent acknowledgment of online reviews affects consumer's attitudes and purchase decision (Chevalier \& Mayzlin, 2006).

TripAdvisor was created in 2000. TripAdvisor is a website based on the idea that travelers depend on other travelers' reviews to arrange their travels and in practice, the reviews could act to influence their decisions to make the trip. Currently, TripAdvisor contains 600 million travel reviews and opinions written by 455 million visitors per month (TripAdvisor Fact Sheet, 2018). TripAdvisor is the world's largest travel site that enables people to share information about their journey on a tourist site and their experiences during their stay in their accommodation. At first, TripAdvisor focused on the experiences of travelers, but by growing the numbers of its unique visitors TripAdvisor has added some features whereby people can book their hotel, vacation rental or attractions from the website. These features are operated under twenty travel brands, e.g., flipkey.com, oyster.com, housetrip.com, etc.

From the previous study, the information society of the new millennium has fundamentally reshaped the way tourism-related information is distributed and the way people plan for and consume travel (Tuominen, 2011). From the websites, the forms of CGC were emerging from various websites such as blogs, virtual communities, wikis, social networks, etc., and have attained significant popularity in online travelers' use of the Internet (Gretzel \& Yoo, 2006).

\section{Methodology}

The focus of the study was on famous tourist destinations in Bali to keep the information search context constant. In this study, descriptive statistics are used to describe the main aspect of the data gathered. Five areas most visited in Bali, from large to small, based on the total number of visitors, the size of the population which also represents acertain geographic diversity, were chosen to exemplify tourist destinations. These popular destinations are: Seminyak, Ubud, Kuta, Denpasar, and Canggu. The five popular tourists destinations were selected based on the most numerous comments and reviews on TripAdvisor. TripAdvisor was selected as the main information source for CGC. Bali was selected based on Travelers Choice Awards from the best 25 places to visit around the world in the year of 2017, according to travelers (TripAdvisor Fact Sheet, 2018). Bali is ranked in fourth place after Paris, London, and Rome. The concept was first to gather all possible review-related data from the TripAdvisor website. These elements included: (1) the number of reviews written; (2) the number of hotel reviews per area; (3) the number of vacation rentals and their reviews; (4) the number of things cited to do and their reviews; (5) the number of restaurants mentioned and their reviews. The methods used for the analysis presented can be summarized as follows: (1) data were gathered on 15 May 2018 from 
TripAdvisor.com; (2) Information about the top five popular destinations in Bali with reference to number of reviews, number of restaurants, number of hotels, and number of things to do were gathered. The data were compared based on forum discussions and rating categories. The following section will discuss the findings. The selections of tourist destinations from TripAdvisor that mentioned tourist destinations was limited to first page (top 20) tourist destination. The majority of search engine users will only review search results in the first three pages based on the past literature (Spink \& Jansen, 2004).

\section{Discussion}

The analysis of the data collected shows that the ranking of the top five tourist destinations in Bali is not based on how many hotels they have, or how many things there are to do. The TripAdvisor ranking order is based on the popularity of vacation rentals by tourist preferences. The results are displayed in Table 1. Vacation Rentals in $\%$ is indeed ordered by the total number of vacation rentals. Seminyak, as the most popular destination, has the biggest total of vacation rentals at 50\%. Ranking second among the popular destinations, Ubud has $15 \%$ which is less than Canggu, which is in $5^{\text {th }}$ position.. However, the categories of the number of vacation rentals do not follow the rating of the top five most popular destinations.

Table 1. Vacation Rentals in Top 5 Popular Destinations in Bali

\begin{tabular}{|c|c|c|c|c|}
\hline Rank & $\begin{array}{l}\text { Popular } \\
\text { Destinations }\end{array}$ & $\begin{array}{l}\text { Number of } \\
\text { Vacation Rentals in } \\
\%\end{array}$ & $\begin{array}{l}\text { Reviews } \\
\text { Vacation } \\
\text { in } \% \\
\end{array}$ & $\begin{array}{r}\text { of } \\
\text { Rentals }\end{array}$ \\
\hline 1 & Seminyak & 50 & 55 & \\
\hline 2 & Ubud & 15 & 19 & \\
\hline 3 & Kuta & 7 & 3 & \\
\hline 4 & Denpasar & 11 & 12 & \\
\hline \multirow[t]{2}{*}{5} & Canggu & 18 & 12 & \\
\hline & Total & 100 & 100 & \\
\hline
\end{tabular}

A vacation rental is the renting out of a furnished apartment, house or professionally managed resortcondominium complex on a temporary basis to tourists as an alternative to a hotel. The term "vacation rental" is mainly used in the US. The first rank of total reviews from vacation rentals is Seminyak. A comparison of the number of hotel in the top five popular destinations is displayed in Table 2. Consumers choose hotels based on reviews and evaluations made on the destination, and their evaluation of previous trips to the destination (Marcussen, 2008).

Table 2. Hotels in the Top 5 Popular Destinations in Bali

\begin{tabular}{clcc}
\hline Rank & $\begin{array}{l}\text { Popular } \\
\text { Destinations }\end{array}$ & $\begin{array}{l}\text { Number of } \\
\text { Hotels in \% }\end{array}$ & $\begin{array}{l}\text { Reviews of } \\
\text { Hotels in \% }\end{array}$ \\
\hline 1 & Seminyak & 19 & 26 \\
\hline 2 & Ubud & 25 & 31 \\
\hline 3 & Kuta & 32 & 25 \\
\hline 4 & Denpasar & 19 & 13 \\
\hline 5 & Canggu & 5 & 4 \\
\hline & Total & 100 & 100 \\
\hline & Source: Author's Data Collection, 2018
\end{tabular}

The choices of tourists are based not only on accommodation (vacation rentals and hotels) but also the tourist attractions. A tourist attraction is a place of interest where tourists visit, typically for its inherent or exhibited natural or cultural value, historical significance, natural or built beauty, offering leisure and amusement. This information comes from Table 3. Things To Do in the Top 5 Popular Destinations in Bali. 
Table 3. Things To Do in theTop 5 Popular Destinations in Bali

\begin{tabular}{clcc}
\hline Rank & $\begin{array}{l}\text { Popular } \\
\text { Destinations }\end{array}$ & $\begin{array}{l}\text { Number of } \\
\text { Things To } \\
\text { Do in \% }\end{array}$ & $\begin{array}{l}\text { Reviews of } \\
\text { Things To } \\
\text { Do in \% }\end{array}$ \\
\hline 1 & Seminyak & 12 & 12 \\
\hline 2 & Ubud & 26 & 42 \\
\hline 3 & Kuta & 21 & 22 \\
\hline 4 & Denpasar & 31 & 21 \\
\hline 5 & Canggu & 10 & 3 \\
\hline & Total & 100 & 100 \\
\hline
\end{tabular}

Source: Author's Data Collection, 2018

For tourist destinations, restaurants are a crucial part of the tourism mix. As with any tourist destination, its restaurants are very important to Bali's tourist industry. Bali now offers an extensive array of restaurants serving world-class food created by world-class chefs, catering for the ever-growing and diverse tourist needs in terms of both quality and price, from budget operations to fine dining establishments. The information from Table 4 shows that the first rank of popular destinations in Bali does not have the largest number of reviews on TripAdvisor.

Table 4. Restaurants in the Top 5 Popular Destinations in Bali

\begin{tabular}{clcc}
\hline Rank & $\begin{array}{l}\text { Popular } \\
\text { Destinations }\end{array}$ & $\begin{array}{l}\text { Number of } \\
\text { Restaurants } \\
\text { in \% }\end{array}$ & $\begin{array}{l}\text { Reviews of } \\
\text { Restaurants } \\
\text { in \% }\end{array}$ \\
\hline 1 & Seminyak & 13 & 31 \\
\hline 2 & Ubud & 21 & 30 \\
\hline 3 & Kuta & 27 & 18 \\
\hline 4 & Denpasar & 31 & 15 \\
\hline 5 & Canggu & 8 & 6 \\
\hline \multicolumn{5}{c}{ Total } & 100 & 100 \\
\hline & Source: Author's Data Collection, 2018
\end{tabular}

In order to offer better value, many restaurants are now turning to using local produce. We have seen a development in local farming in the north of Bali. The growth of the restaurant sector is still high in Seminyak Area. Not only restaurants, but warungs and street stalls are also very popular and found throughout Bali. Various local dishes and snacks are sold in this type of venue and consumed by tourists.

\section{Conclusion}

To briefly summarize, the present study found that popular destinations do not have to have the largest number of reviews in every aspect in order to rank first. TripAdvisor is the platform designed to achieve a deeper consideration about the the way tourist attractions, tourists and residents of a given destination are altering the tourism online maketplace. The modern tourist nowadays is searching for personalized services that address their preferences and interests. However, tourism companies have to make some effort to get more information about their clients to give them relevant information. From TripAdvisor, tourists can get information about destinations, and book tickets and hotels. Tourists can also leave reviews about the destination they have visited, for subsequent tourists. Therefore, TripAdvisor was chosen as the subject of the research. The data that was collected shows that the total of hotels does not show the first rank. From the data collected above we can conclude that TripAdvisor has all the important tools for arranging a trip. TripAdvisor offers the opportunity to find crucial information, to book a hotel or ticket, read reviews and write about one's experiences for subsequent travelers on the website. The availability of getting and reading feedback has brought benefits from using TripAdvisor. 


\section{Acknowledgments}

I would like to show my gratitude to Prof. Sigit Pranowo Hadiwardoyo, DEA and Dr. Deni Danial Kesa for sharing their prudence and knowledge for this study. The assistance of both scholars is gratefully acknowledged.

\section{References}

Amaral, F., Tiago, T., \& Tiago, F. (2014). User-generated content: tourists' profiles on Tripadvisor. International Journal of Strategic Innovative Marketing, 1(3), 137-145.

Buhalis, D., \& Law, R. (2008). Progress in information technology and tourism management: 20 years on and 10 years after the Internet-The state of eTourism research. Tourism management, 29(4), 609-623.

Chevalier, J. A., \& Mayzlin, D. (2006). The effect of word of mouth on sales: Online book reviews. Journal of marketing research, 43(3), 345-354.

Gretzel, U., \& Yoo, K. H. (2006). Consumer generated content - trends and implications for branding. E-Reviews of Tourism Research, 3(3), 9-11.

Kang, M., \& Schuett, M. A. (2013). Determinants of sharing travel experiences in social media. Journal of Travel \& Tourism Marketing, 30(1-2), 93-107.

Liu, H., Wu, L., \& Li, X. (2019). Social media envy: how experience sharing on social networking sites drives millennials' aspirational tourism consumption. Journal of Travel Research, 58(3), 355-369.

Marcussen, C. H. (2008). Trends in European Internet distribution of travel and tourism services. Centre for Regional and Tourism Research, Denmark.

Miguéns, J., Baggio, R., \& Costa, C. (2008). Social media and tourism destinations: TripAdvisor case study. Advances in tourism research, 26(28), 1-6.

Mihalcescu, C., Sion, B., \& Marginean, A. (2016). The development, success and impact of electronic tourism in the digital age. Journal of Information Systems \& Operations Management, 416.

Paulina, B., Cezar, B., \& George, C. (2009). New methods regarding the organization and functionality of the business environment in the virtual economy. Annals of the Oradea University, 18(4), 908-913.

Spink, A., \& Jansen, B. J. (2004). Web search: Public searching of the Web. New York: Kluwer.

TripAdvisor Fact Sheet http:// https://tripadvisor.mediaroom.com/US-about-us (accessed 15/05/2018).

Tuominen, P. (2011). The influence of TripAdvisor Consumer-Generated Travel Reviews on Hotel Performance. Journal of Hertfordshire Business School.. 